collection is worthy of a more detailed comparative study than that to which it has hitherto been subjected, and among the undescribed specimens most readily identified is a small fossil indistinguishable from the so-called "intermandibular arch" or "presymphysial bone" of Onychodus." Through the kindness of Prof. Lindström, this specimen has been forwarded to the British Museum for examination, and it forms the suhject of the following remarks.

Four fractured teeth are exhibited, attached in close series to a narrow arched base, and the fossil is firmly imbedded in a hard matrix. It is evidently imperfect, but the base preserved is 0.005 in length, and the uppermost and longest tooth has a nearly similar measurement. This tooth is slender, tapering, and gently curved, without any sigmoidal twist; and both it and the more imperfect teeth below are characterized by the relatively enormous size of the internal cavity.

In its small dimensions the presymphysial dentition from Spitzbergen most nearly approaches that of Onychodus anglicus, ${ }^{2}$ from the Lower Old Red Sandstone Passage Beds of Ledbury, Herefordshire; but it is distinguished by the more uniformly tapering character of the teeth, and the relatively larger size of the pulp-cavities. In the latter feature it seems to be more nearly paralleled by the much larger, typical species from the Devonian of the United States; but all described forms differ from the new fossil in the larger size of - the teeth in proportion to their base of attachment. The Spitzbergen species, thus imperfectly indicated, may therefore be regarded as hitherto unknown, and, in reference to its interest from a distributional point of view, may be named Onychodus arcticus.

\title{
NOTICES OF MFMOIRS.
}

The Geology of Devon, Faots and Inferences, from the Presidential Adpress to the Devonshire Association. By W. H. Hudleston, Esq., F.R.S., Sec.G.S., etc. August, 1889.

WTE can have little doubt that this South-western part of England had the honour of leading off the Greological Surveys of the world because of its great metallic wealth, and because of the interesting and complicated phenomena associated therewith. But it must not bo supposed that the early Surveyors settled every question fifty years ago, especially when we bear in mind the varied nature of the region, the obscurity of many of the problems, and the comparative novelty of the task. Devonshire especially has been the theatre of many a geological battle since then, nor can we aver that the temple of Janus is at present closed. It is twenty-one years ago, I believe, since a President of the Devonshire Association dealt with any of these topics from the chair. Mr. Pengelly, in the year 1868, after giving an admirable summary of

1 J. S. Newberry, Geol. Survey of Ohio, vol. i. pt. ii. (Palæontology), pp. 296-302, pts. xxvi. xxvii.

${ }^{2}$ Smith Woodward, "Note on the Occurrence of a Species of Onychodus in the Passage Beds of Ledbury," Geor. MAG. Dec. III. Vol. V. (1888), p. 500. 
the progress of geology in Devonshire up to that date, propounded nine questions for special consideration in the future. These I venture to recall to your memory-

1. The age of the crystalline schists of the Bolt.

2. The precise chronology of our Limestones and associated rocks.

3. Is there east of Exmouth a break in the Red rocks?

4. Whence come the Budleigh Salterton pebbles?

5. Whence also the porphyritic trap nodules so abundant in the Trias?

6. Are our Greensands really of the age of the Gault?

7. Whence the flints so numerous in our existing beaches?

8. What is the history of our superficial gravels, and are there any indications of glaciation in Devonshire?

9. To what race did the Cave-men belong?

During the interval of over twenty years most of these questions have been discussed, often by Mr. Pengelly himself, and the records are to be found in the volumes of your Transactions. Confining any remarks I may have to make on the present occasion to points bearing on the physical history of the county, I would say that these questions may be grouped under five beads-(1.) Recent and Pleistocene geology; (2.) The extent and nature of the Cretaceous rocks; (3.) The New Red question; (4.) The Old Red question ; and lastly (5.) The age of the crystalline. schists, to which may be appended any necessary remarks on petrological questions.

Recent and Pleistocene Geology.

The recent geology of the county is famous, as all the world knows, for the occurrence of raised beaches, submerged forests, and bone caves. On these I scarcely venture to touch, the cave-question especially verging on the confines of archroology. If the caverns at Oreston were first made the subject of scientific enquiry, those of Kent's Hole and Brixham have yielded results of surpassing interest. Going a step further back in time, there are few problems more obscure than the history of the plateaux gravels of the southern counties : these consist largely of flint. Mr. Parfitt, speaking of the drift gravels towards Dawlish, has expressed his opinion that the agents producing these were ice and water. To this we can scarcely demur, but it was hardly necessary to have included Devonshire in the ice-sheet. The indications of glaciation in this county are matters of inference rather than self-assertion, and observers, like Mr. Somervail, accustomed to the marked features of a thoroughly glaciated country, are slow at finding any evidence of it here. Still it must be obvious to all who reflect upon the subject that the cold which has left such enduring evidences of its intensity in areas so near, for instance, as Caernarvonshire, must have affected the Devonshire climate to a considerable extent. The absence of true Boulder-clay should reconcile the Devonian to the fact that his country is destitute of cowslips, which are very partial to the Boulder-clay soils of the North of England, and are far from scarce in the heavily-bouldered regions of East Anglia. It is true that the 
Swedish botanist Nathorst, speaking of the peculiar mixture of clay and stones known as the "Head' of Bovey Tracey," called it Boulder-clay; and Mr. Pengelly likewise mentioned lately that another Scandinavian authority, Dr. Torell, when in company with Mr. Ormerod as long ago as 1868 , professed to have detected three moraines on Dartmoor in the neighbourhood of Chagford. That these were the results of an ice-cap, as that term is generally understood, I do not regard as probable; but bearing in mind the recorded facts, and also the frequency of such features as "terminal curvature," we may well believe with Mr. Worth in the existence of something like a local snow-cap on the higher grounds. The peculiar nature of the cave-breccia, and the Arctic character of some of the caveanimals, also point in the direction of a colder climate. Not that this evidence is really required, except as a matter of corroboration. We may believe, then, in a glaciation so modified that its results require close search before they can be appreciated.

\section{The Extent and Nature of the Cretachous Rogks.}

There are few problems in the physical history of the South-west of more interest than this. Speaking of the geology of the neighbourhood of Dawlish, Mr. Ussher says there can be little doubt tbat the Cretaceous highlands of Devon, such as the Haldons, are portions of a great plain of marine denudation, and he speaks of a time when that Cretaceous tableland abutted on the flanks of Dartmoor. $\mathrm{He}$ also refers to the presence of flints in the old and more modern gravels as evidence of the extension of Chalk débris. It is interesting to know that abundant fossil evidence of the former existence of Middle Chalk (the Upper Chalk of some writers) is found in the chert and flint beds which form the capping of Little Haldon; the Echinodermata are especially characteristic. Mr. Ogilvie Evans has called attention to this fact.

As regards the former extension of the Chalk, I see no reason to doubt that the western part of what is now the Channel and the greater portion of Devonshire and Cornwall were submerged beneath the Chalk Sea. It seems to me that in no other way can you account for the quantity of flints on the western beaches and in the bottom of the Channel. But, irrespective of this corroborative evidence, one would expect the Chalk Sea to have extended in this direction. Then comes the question, Was there any western limit to the Chalk Sea, or did its waters mingle freely with the Atlantic Ocean during the period of extreme depression? At the epoch when the Upper Greensand, or basal sediment of the Chalk, was being laid down, Mr. Jukes-Browne, in his "Building of the British Isles," represents the extreme western shore-line, plotted on the existing map of Devon as passing from the Ermemouth towards the Haldons; i.e. roughly parallel to the E.S.E. flank of Dartmoor. Now the distance from the Ermemouth to the present edge of the deep Atlantic basin is about two hundred miles, and that two hundred miles would represent the width of the land which intervened between the Upper Greensand Sea and the Atlantic Ocean at the 
particular period indicated in the hypothetical map to which I have referred. It is a question for separate consideration whether that intervening space of land was wholly or only partially submerged at a later epoch during the period of extreme depression. For our purpose it will be sufficient to have carried the western margin of the Chalk Sea beyond the limits of the Cornish peninsula during the period of lowest depression, and this I think we may fairly claim. I ought to observe that it is not assumed that the English Channel had any existence at that time. Mr. Jukes-Browne regards the Channel as a very modern feature in physical geography, but the existence or non-existence of the Channel as a mere excavation will hardly affect the question of the westward boundary-line of the Chalk Sea.

One more question of Mr. Pengelly with reference to Cretaceous geology remains, viz. the age of the Devonshire Greensand. It was Fitton, and after him Meÿer, who maintained that the Blackdown Beds were of Lower Cretaceous age, although before their time De la Beche had classified them as Upper Greensand, whilst Godwin-Austen described them as possibly a sandy condition of the Gault. The littoral facies and abundance of Trigonice, having considerable resemblance to Lower Greensand species, led Mr. $\mathrm{MeY}_{\mathrm{er}}$ astray. Dr. Barrois and other authors entered the lists, and when Mr. Downes read his excellent paper before the Geological Society in 1881, the balance of opinion tended to the view that the Gault, or most of it, is represented in the Blackdown Beds, and that seemed also to have been Mr. Downes' opinion. If the Ammonites in that gentleman's collection have been correctly determined, there would seem to be a mixture of Lower-Gault with Upper-Gault forms; but as the Upper-Gault of the East of England is represented to a considerable extent in the West by the Upper Greensand, it follows that, if we allow most of the Gault to be represented in the Blackdown Beds, such a determination carries the Upper Greensand with it, so that both De la Beche and Godwin-Austen were right.

There is not a trace of Lower Greensand, and when we bear in mind that the Lower Greensand has already disappeared to the eastward, its revival at Blackdown would be an anomaly. But a further argument in this direction, which Mr. Downes, aided by Mr. Vicary, was the first to indicate, is derived from the fact that the nine lowest horizons indentified at Blackdown are missing at Haldon. This proves conclusively that the basal rocks of the Upper Cretaceous ever occupy a higher horizon as we proceed westwards, and, as we have already seen, this has an important bearing on the question of the final westward limit of the Chalk Sea. It is quite possible also that the missing beds of Chalk were more siliceous than their equivalents further eastwardly, and this would still further help to account for the flints so numerous in the Channel and adjacent shores.

There are two points in connection with Blackdown which might be mentioned: 1st, Mr. Downes read a paper before the Geological Society in November, 1884, "On the Cretaceous Beds of Black 
Venn, with some supplementary remarks on the Blackdown Beds." There he appeared to arrive at the conclusion that the Lima. parallela-bed of Black Venn is lower than the lowest of the Blackdown Beds, for it thins out before reaching Sidmouth. He again notices the general thinning out westwards. These latter conclusions are somewhat at variance with his previous ideas that the Blackdown Beds represent the whole of the Gault, and he finally inclined to the opinion that the Blackdown Beds were Upper Greensand rather than Gault. I have before pointed out that the Upper Greensand partly represents the Upper Gault of the south-east of England, and this interpretation will belp to explain the apparent contradiction.

2nd. The mode in which the clumps of Turritella and Pectunculus occur in the Blackdown Beds reminds me of the similar way in which their modern representatives occur in the English Channel. Not far from Hope's Nose is a muddy bed full of Turritella, showing how the shell is apt to accumulate from some cause or other in one or two particular spots, and throughout the Channel it is by no means uncomnon to come across Pectunculus in great numbers at particular spots.

\section{Nhw-Red Beds.}

The New-Red question next demands our attention, since the Jurassic rocks of Devonshire are limited to a very narrow strip of Lias in one corner of the county. The phenomena in connection with the New-Red beds are of great interest in spite of their poverty in organic remains. We are as much interested in the composition of these beds as in ascertaining their precise chronological value. Thus two of Mr. Pengelly's questions relate to the composition of Triassic pebble-beds. It would certainly appear from Mr. Davidson's determination of the Brachiopoda that a considerable portion of the Budleigh-Salterton pebbles were of Devonian origin or aspect, although there are a sufficient number of admitted or possible Silurian species. Thus Salter's original proposition that they are Normandy types of the May-Hill Sandstone may in part be correct, the fossils being characteristic of beds on both sides of the Channel. The rocks from which such pebbles were derived are certain to be no longer in existence; the pebbles themselves are mere survivals of an ancient denudation, just as is the case with the flint pebbles whose origin we have lately been considering. It is not difficult to believe that both Silurian and Devonian beds were largely developed in portions of what is now the Channel area. Indeed the form of the present peninsula of Normandy clearly points in that direction, whilst projections of Palæozoic rock from what is now the DevonCornwall peninsula may likewise have contributed their share. Hence an extension of the Gorran Haven beds, or of La Manche, points almost equidistant, may have been amongst the missing rocks from whose bardest parts some of these pebbles were long ago torn. There is no evidence, so far as I am aware, that the English Channel, in anything like its present form, had any existence in Mesozoic times, and we may well believe this without going so far as Mr. 
Jukes-Browne, who represents the English Channel as merely a feature of Pleistocene geography. Doubtless the origin of the English Channel is a problem well worthy the attention of Devonshire geologists, but at present we are considering the composition of Triassic pebble-beds, and must not, therefore, allow ourselves to be led off on a false scent.

Mr. Pengelly's other question, as to the origin of the porphyritic trap nodules, is one which embraces a far wider scope; for along with it must be considered the subject of igneous fragments in the New-Red generally. One would be disposed to say that most of them were derived from the felspathic traps, so many of which make their appearance at the junction of the Carboniferous and Now-Red. This peculiarity of position Mr. Vicary was disposed to attribute to the circumstance that these traps have served to arrest denudation in the Trias. It is said that none are to be seen in the coast section. Mr. Vicary regarded the earliest eruptions of this class of rock as having taken place between the close of the Carboniferous and the commencement of the Triassic, whilst the latest outbursts were of Triassic age. Mr. Downes also, whilst endeavouring to account for the presence of some Upper Devonian fossils in the Trias near Tiverton, has expressed his opinion that the hypothesis of an active volcano upon the coast of the early Triassic sea best meets the requirements of the case. Mr. Somervail likewise has expressed his views on the probable volcanic origin of the breccias at the base of the Trias in South Devon, and as to the conditions prevailing during their accumulation.

It cannot be doubted that a careful and unprejudiced study of the igneous rocks in the Devonshire Trias will help to throw much light on an important stage in the physical history of the area. But in undertaking such an investigation due allowance must be made for the changes which the fragments have themselves undergone in a highly permeable formation. If lumps of hard limestone, under the influence of siliceous infiltration, have been converted into that peculiar form of orbicular silica known as "Beekite," we need not be surprised at felspars, derived originally from Dartmoor, having been converted into Murchisonite, which chemically differs from orthoclase mainly in containing somewhat more alumina.

And thus it came to pass that pieces of Dartmoor granite were unrecognizable, whilst a generation of geologists, following De la Beche and Godwin-Austen, were disposed to believe that during the New-Red epoch, the granite of Dartmoor had not as yet reached the surface. Lately, speculation has taken quite a different turn. $\mathrm{Mr}$. Worth is disposed to think that the granite of Dartmoor passed upwards into felsitic and volcanic rocks, remnants of which, be says, are to be found in the Triassic conglomerates of the county. Geologists, therefore, having started with the belief that the Dartmoor granite was covered up by sedimentaries in Triassic and pre-Triassic times, are now presented with a picture of a pre-Triassic volcano towering into the skies. It is also intimated that andesites and specimens of volcanic grit such as arise from the denudation of volcanic cones have been found in much more recent deposits. 
Confining our attention for the present to the New-Red rocks, one would suppose that if the above speculations have a good foundation, the evidences of volcanic rocks derived from the disintegration of the old Dartmoor volcano ought to have been much more abundant in the Triassic conglomerates than they have hitherto seemed to be. $B$ at the further investigation of this matter must be deferred until we have considered the chronology of the New-Red beds.

We now perceive the import of the question put by our propounder of riddles, "Is there east of Exmouth a break in the "red rocks'?" So recently as $1881 \mathrm{Mr}$. Pengelly wrote: "I incline to the opinion that our Red Rocks, taken as a whole, belong to the Keuper; or, if not, that all three sub-systems of the Trias are represented in Devon." Of course, when Mr. Pengelly thus infers the existence of the middle member of the Trias, he can only mean that the Muschelkalk is represented in time.

Mr. Ussher, four years previously, had given in the Transactions of the Association the results of his experience in the classification of the Triassic rocks. His view was that whilst in the Midlands there is complete unconformity between the Bunter and Keuper, in Devonshire the Triassic beds present a conformable series. He also showed that the beds cut out at Straight Point and Exmouth, in the south-coast section, are visible in the inland districts, thus practically answering Mr. Pengelly's question in the negative. The once prevalent notion, therefore, that the whole of the Devonshire Trias is of Keuper age, a notion which seemed to have the support of high authority, must be abandoned. A series of marls and sandstones, called by Mr. Ussher "Middle Trias," he thought might roughly represent the Muschelkalk in time, whilst his "Lower Trias," consisting of sandstones and breccias with igneous fragments, so well developed between Dawlish and Watcombe, is mainly of Bunter age. The older beds would presumably occur to the westward, but there does not seem at this time to have been a suspicion of Permian on the part either of Mr. Ussher or Mr. Pengelly. Mr. Ormerod, in his notes on the deep borings in the Trias at Teignmouth, also describes the beds between the Exe and the neighbourhood of Torquay as belonging to the Bunter.

In a communication to the Geological Society Mr. Ussher speaks of the lowermost beds of the soutb-cuast Trias as far exceeding their more northerly equivalents in thickness, and as affording a strong probability that a reconstruction of the English Channel valley would exbibit a still greater development of beds, dating as far back perhaps as late Permian times. It is thus evident that Mr. Ussher considers that a large extent of New-Red rock has been destroyed in the formation of the English Channel, and possibly portions may yet be proved in the bed of the Channel itself. Mr. Worth, as you know, considers that he has evidence of the existence of Triassic rocks in situ fifty miles to the south-west of the Triassic outlier at Cawsand, in Plymouth Sound, but it is rather a peculiar feature in this case, that the supposed submarine 'Trias resembles the Keuperian or eastern variety of the Devonshire Red Rocks. Mr. 
Irving, who has paid some attention to these questions, differs from Mr. Ussher, and still more from Mr. Pengelly, in the belief that the breccia series is of Permian age. He regards it, in fact, as the result of terrestrial and littoral deposits on the flanks and on the shoreline of the old mountain region of which the Devon-Cornwall peninsula is one of the remnants, the high inclination of the dip being in favour of its being mainly composed of mountain detritus.

It would be difficult indeed to assign any other origin to the wonderful group of beds which constitute the sea-cliff between Teignmouth and Dawlish. The only matter in dispute is the precise chronology of these beds. Shall we say with Mr. Pengelly that they are of Keuper age? or with Mr. Ussher and Mr. Ormerod, that they are of Bunter age? or shall we agree with Mr. Irving that they are of Permian age? In the absence of marine mollusca the precise age of any series of beds is difficult to determine; all that we can affirm with absolute certainty is that they belong to the Permio-Triassio interval, and that in this country such beds are more usually Permian than Triassic. The brecciated beds of the Leicestershire Permians, for instance, have been recently shown to be composed of the re-arranged talus of the harder portions of the Palæozoic rocks surrounding that part of the old Permian lake.

\section{The Post-Carboniferocs Interval.}

Leaving the question of the actual chronology of the Dawlish beds as almost hopeless in our present state of knowledge, we must be content to bear in mind the main facts of the case, viz. that towards the close of the Carboniferous period one of those great shifts in the earth's crust occurred, of which there have been three or four during geological time. Roughly speaking the Palæozoic epoch terminated with this great movement, whose flexing action has, in the main, governed the axes of the series of synclinals and anticlinals existing between the Bristol and English Channels, with an extension towards the south so as to include the peninsula of Brittany. The principal of these earth-throes occurred during the unrepresented period of time which intervened between the Coalmeasures, as usually developed, and the Permian; and though there are evidences of subsequent oscillation in our district to a moderate extent, no instances of folding and contortion occur in the beds deposited afterwards. Then it was that the building of the British Isles commenced in earnest, and that the first rude sculpturings of the future Devonshire were made. Some of these points we shall have to consider again in reference to the general structure of the county.

\section{The Carboniferous.}

Before proceeding to answer the remainder of Mr. Pengelly's questions, a few words may be devoted to a formation which in Devonshire is both extensive and disappointing. No attempt will be made to correlate any portions of these beds wih their presumed equivalents on the Welsh side. All we can say is, that 
the Old-Red of the Welsh border does not differ from the Devonian of Devonshire more than does the Carboniferous of Wales from beds of the same system in this county. The Culm-measures are something sui generis, and it seems difficult to account for their origin.

It may be worth mentioning in this connection that Dr. Barrois, speaking of the physical history of Brittany, which presents certain analogies with that of our south-western peninsula, observes that the Carboniferous period in that region was one of oscillation between terrestrial and marine conditions-a period of extensive eruptions and great earth movements. Hence he says that a considerable portion of the sediments, especially towards the base, are of volcanic origin. This is not at all the case with the Carboniferous in North Devon, where the sequence is undisturbed. According to the views generally accepted, the main horizon for contemporaneons igneous rocks in the Palæozoio of Devonshire lies in the Lower Devonian, though there seems to be some difference of opinion upon this point.

\section{The Ord-red or Devonian Question.}

This may with justice be termed the home question; but in order to attempt a solution, it will be found necessary, in the first instance, to take into consideration the Old-Red Sandstone of other areas. The claim of the Devonian to recognition as one of the great geologioal systems has been challenged more than once; and even when this has not been disputed, there have been divers contradictory efforts to fit in the marine Devonians with the several members of the Old-Red Sandstone. In North Devon the matter was further complicated by the great Jukesian heresy, based on the alternative supposition of a concealed anticlinal with an inversion towards the north, or more probably an east and west fault. These ideas, as you know, were successfully combated by $\mathbf{M r}$. Etheridge and $\mathbf{M r}$. Townshend Hall in the earliest days of the Association; and about ten years ago the latter gentleman reviewed the history and classification of the North-Devon Rocks in an able paper which appeared in the "Transactions." His own classification of the North-Devon beds differs in details from that adopted by Ussher and Woodward; but this is a matter of minor importance, since all agree in regarding the Ilfracombe limestones and associated slates as a definite central datum line, from whence to proceed either above or below. Mr. Hall observes that the North-Devon beds from Lynton to Pilton, though preserving a general dip to the sonth, are folded into many anticlinals, reducing their apparent thickness very considerably.

Having got the North-Devon beds, which are really the key to the whole Devonian system, into something like order, it now becomes necessary to quit the county for a while in order to study the Old-Red Sandstone on the other side of the Bristol Channel. And here we realize the fact that there are two Old-Red Sandstones, the Lower of which is perfectly conformable with and passes down into the underlying Silurian, whilst the Upper passes conformably into the Carboniferous, of which system, in a certain sense, it may. 
be regarded as the base. It is only in recent years that this unconformity between the Lower and Upper Old-Red Sandstone has been fully recognized. Moreover, this is by no means a local phenomenon confined to the Welsh districts, since in the South of Ireland there is a great hiatus between the presumed equivalents of the Pickwell Down beds above and those of the Lynton beds below. Thus both in the South of Ireland and in South Wales the time representatives of the Ilfracombe and associated beds are absent. These three districts are more or less involved in the great post-Carboniferous east-and-west folding, and may be said to belong to the same system of physical disturbance. But even in Scotland Hugh Miller's Old.Red Sandstone is found to consist of two portions, the lower part shading off into Silurian, the upper into the Carboniferous. Thus, throughout the British Isles, what was formerly known as the Old-Red Sandstone is found to consist of two very distinct members, widely separated from each other in point of time, each having affinities with the neighbouring system. If, then, the case rested on the Old-Red Sandstone alone, its fate would only differ from that of Poland in being partitioned between two instead of three ambitious neighbours.

Having learnt thus much with regard to the Old-Red Sandstone, it is now time to return to North Devon, where we have a fossiliferous series interposed between beds which are held to be the equivalents, mutatis mutandis, of the Lower and Upper Old-Red Sandstone respectively. It is these fossiliferous beds which forge the link that was missing, whilst the intermediate yet independent character of their fauna justify, on palæontological grounds, their being regarded as the head-quarters of a distinct and separate system. The more copious development of the remains of marine organisms in the corresponding beds of South Devon further justify the original determinations of Lonsdale. It is these central beds, therefore, which constitute the backbone of the Devonian system; and if the correlations to which I have alluded be substantiated, they must carry with them the Upper and Lower Old-Red Sandstone as integral parts of that system.

It seems to be generally admitted that the Pickwell-Down beds are really the equivalents of the Upper Old-Red Sandstone. Perhaps it was Professor Hull who first suggested this, but nearly ten years ago Mr. Champernowne, whilst agreeing that the Pilton and Marwood beds should be referred to the Carboniferous, considered the Pickwell-Down Sandstone to be true Old-Red Sandstone, and also Upper Devonian. The fact of the Pickwell-Down beds being unfossiliferous lends additional probability to this view. The correlation of the lowest Devonian beds with the Lower Old-Red Sandstone seems more open to discussion. In the first place the subject is complicated by the suggestion that the Foreland and Hangman Grits are repetitions of the same beds by means of faulting, and secondly the arenaceous beds of the Lower Devonian in North Devon yield some marine mollusca. The resemblance of the Foreland Sandstones to the Glengariff Grits was regarded by 
Professor Hull as most striking. On the whole there still seems a little obscurity as to the details of the lowest Devonian beds on the Bristol Channel.

There would be no use in considering the Devonian sequence in South Devon until that in North Devon had been fairly settled. It is not always that opportunities are afforded for studying a set of beds in duplicate within a limited distance, but I have had occasion to notice, more than once, the very great differences of development that present themselves under such circumstances within areas not so very far apart. Doubtless the original differences were very considerable, since South Devon must be regarded to a certain extent as a reef region, and the beds moreover were largely reinforced by contemporaneous volcanic matter of a basic nature, from which the equivalent beds in the North Devon area were almost entirely free. But in addition to these congenital elements of difference are others belonging to a subsequent period, such as a further extravasation of igneous rocks, and above all the extraordinary folding and compression to which the beds have been subjected. The confusion is something terrible, and we may regard the district as praotically unmapped, although, thanks to Mr. Champernowne and others, a certain amount of correlation with the North Devon beds bas been established.

The backbone of the system is constituted by the Great Devon and Plymouth limestones with their associated upper and lower slates, the upper or Dartmouth slates more especially corresponding with the Morte slates of North Devon. Underlying these central beds, or Middle Devonians, are the Torquay Grits, containing the Homalonotus-beds, some of which struck Mr. Champernowne as being suspiciously like certain Ludlow rocks. These of course are naturally correlated with the Hangman Grits and Lynton Slates. Whether beds as low, or even lower than these, occur in any other part of South Devon, I am not in a position to state; but the beds of Yealmpton Creek have been placed on this horizon, and some geologists have even spoken of Silurian beds in the country north of Tavistock. On the other hand, the Upper Devonian, according to Mr. Champernowne, is represented by the Cockington Grits, originally. described by De la Beche as Old-Red Sandstone, and these are the equivalents of the Pickwell-Down beds of North Devon. For Mr. Champernowne the Upper Devonian would appear to terminate with these beds, which he correlates with the Psammites du Condroz. Mr. Ussher, in describing the relatidns of the Devonian and Culm rocks on the east side of Dartmoor, observes that, as a rule, the Upper Devonian rocks occur in faulted association with the basement-beds of the Culm-measures. But in the area between Bovey Tracey and Bickington the uppermost Devonian beds are irregular slates, similar to the Pilton beds, and in one or two unfaulted junctions they pass up into Culm-measures, which are overlain by indurated shales of the Coddon Hill type. These recent observations of $\mathrm{Mr}$. Ussher would seem to complete the analogy between the Devonian rocks in North and South Devon. 
It would be beyond the limits of a Presidential Address if I were to follow this very interesting subject much further on the present occasion. I hope to have demonstrated that considerable progress has been made with the Devonian question during the last twenty years, although, as stated by Mr. Whidborne, in his preface to the "Devonian Fauna of the South of England," the correlation of the different parts of the system with the major divisions in America and the Continent is still a matter of discussion. Crumpled up and reversed as the beds are in South Devon, their stratigraphy will always be complex; but it is probable that in their original condition there was considerable resemblance to the Rhenish and Belgian Devonians, pointing to the prevalence of fairly similar conditions during the period of deposition.

Referring to the subject of correlation with Continental beds, there is an article in the "Neues Jahrbuch" for the present year "On the Devonian of Devonshire and the Boulonnais," writted by Herr Kayser, which, he says, is the outcome of a trip to the South-west after the Geological Congress of last autumn.

Herr Kayser finds in South Devon a development which intimately approaches the West-German. In the Upper Devonian of that region he recognizes nodular limestones with Clymenia (more typically developed at South Petherwin), "Cypridinen-schiefer," Adorf Goniatite-limestone, Büdesheim-shales, and Iberg Coral- and Brachiopod-limestones. In the Middle Devonian he recognizes Stringocephalus-limestone, Calceola-limestone, Calceola-shales, and possibly also Goslar-beds. In the Lower Devonian be finds the Upper and Lower Coblenz stages and "Siegen-Grauwacke" especially represented by a small but typical fauna at Looe. This general agreement is further increased by the appearance of numerous "greenstones," which, just as in Nassau and the Harz, are accompanied by schalsteins.

He notes the difference of development in North Devon. In the Upper Devonian the Clymenia-limestone, the Adorf Goniatite-limestone, and the Iberg coral-limestone are missing. In the Middle Devonian he notes the absence of the great Stringocephalus- and Calceola-limestones of South Devon. The Lower Devonian of this area, with its preponderance of hard quartzitic sandstones and grauwackes, does not for the present permit of any close comparison with the Rhenish or Belgian-French Devonian. He recognizes the horizons of the Pilton beds and of the Cucullea-zone, or Baggy beds, which seem to have their Continental analogues rather in Belgium than on the Rhine, but there is nothing in those countries to represent the Pickwell-Down Sandstone. So likewise the phyllitic shales of Morte and Ilfracombe, which alone represent the whole Middle Devonian of North Devon, are equally without analogues.

From the above we may fairly conclude that the North-Devon beds have very little in common with the Devonians on the Continent. But it is mainly through the North-Devon Beds, as we have already seen, that the Devonians generally can be made to fit in with the two members of the Old-Red Sandstone. Both geographically and in character the North-Devon beds occupy an intermediate 
position between the calcareous-volcanic Devonians of the Sonth and the coarse quartzose sediments of the Welsh border, altogether devoid of mollusca. If we regard the "Old-Red" of South Wales as an inshore deposit over an area which was deluged with fresh water from off the land, we can believe that further out to sea, in the times of the Lower Old-Red, conditions were favourable for a moderate amount of marine mollusca. This does away with the necessity for a barrier, and also, in a general sense, it suggests a kind of gradation between the Old-Red, the North Devon, and the South Devon deposits.

BoLT Rocks, ETC.

The age of the crystalline schists of the Bolt.-Besides the mere chronology of the subject, there are questions of considerable interest in connection with these schists, the consideration of which more or less involves the physical history of the bed of this part of the Channel, as well as of the adjacent lands. In this connection also we may endeavour more especially to review the physical structure of the entire South-west, to which allusion has already been made in reference to the effects of the great post-Carboniferous disturbance so obvious throughout Devonshire.

The subject generally is by no means ripe for final decision, and even if we limit our observations, in the first instance, to the Bolt Rocks and their submarine connections, real or supposed, we must allow that, if metamorphism has usually proved an obscure question, the study of metamorphism under water is hampered with additional difficulties. There are no rocks in the county whose age and origin, even to this day, are so wuch debated as those which, speaking generally, we may term the Bolt Rocks.

of the numerous theories which have been advanced, the most doubtful, it seems to me, is that which regards the mass as the result of progressive metamorphism from the action of underlying or contiguous submarine granite. Allowing, for the sake of the argument, that there is progressive metamorphism, although Prof. Bonney and Miss Raisin distinctly deny it, there is very little in the chlorite- and mica-schists of the Bolt district which resembles the peculiar fringe of partially metamorphic rock due to contact with a granitic mass. Such fringes are usually marked by abundance of andalusite, amongst their other characteristics, especially when slates are invaded. Yet we do not hear of this mineral in connection with the Bolt Rocks, though it must be admitted that the microscope bas revealed the existence of kyanite, hitherto unsuspected.

Let us now for a moment examine the case for progressive metamorphism, which has found a recent advocate in Mr. Somervail. Many of us perhaps, in common with that gentleman, fail to understand why all metamorphic rocks, not absolutely the result of contact action, should be claimed as Archæan. But this unwillingness to accept their Archæan age does not compel us to believe that there has been progressive metamorphism, whereby an extension of the Dartmouth Slates, even with the addition of interbedded igneous rocks, has yielded, under peculiar circumstances, the mica-schists and chlorite-rocks of the Bolt. Mr. Somervail's argument, that the 
chlorite rocks are the metamorphic equivalents of interbedded sheets of igneous rock on the north side of the syncline, though ingenious, is scarcely convincing. A series of chemical analyses at this stage of the argument would be useful. On striking the balance of evidence it seems probable that the slaty beds are wholly distinct from the true metamorphic rocks in the south. If reliance is to be placed on the microscope, this must be regarded as proved. I would remark also, that few things are more deceptive than an apparent sequence in a highly compressed region; so that the presence of a fanlt is more often a matter of inference than of direct observation in such districts.

It is not absolutely necessary for us to believe that the crystalline schists of the Bolt are of Archæan age, if indeed we know exactly what is meant by Archrean. But I think that there are fair reasons for considering them to be older than the Devonian against which shey abut; and that, in point of fact, they owe their present position so having been involved in the anticlinal uplift of which there are races here and there along the channel shores of the Devon-Cornwall reninsula.

And this brings me to the consideration of the general structure If Devonshire from a stratigraphical point of view. Regarded as i whole, every one knows that Devonshire is a broad synclinal. Ihe Lower Devonian beds of Torquay on the one side and of Linton in the other are practically on the same horizon, and, omitting minor urves and breaks, the extensive region between these two points $s$ one great trough of Palæozoic rocks. But if we start again from he neighbourhood of Torquay in the direction of Dartmoor, it is till found that, on the whole, newer beds come to the surface as be south-east flank of the granite mass is approached. No matter low the beds in the immediate vicinity of the granite may be iffected, the south-east flank of Dartmoor must be regarded as lying $\mathrm{n}$ a depression, relative to the coast rocks at the points already nentioned. Again, shifting our position considerably with regard o the central mass of granite, we find a suspicion of Lower Devonian ocks at Yealmpton, and a certainty of them at Looe, all pointing to he conclusion that there are traces of the northern wing of an nticlinal on the Channel coast. An inner and more deeply-seated cortion of this anticlinal, in places resulting in a dislocation and ossibly an inversion, has brought up the crystalline schists of the 3olt. With these perhaps may be associated inferentially the ;neissic rocks in the neighbourhood of the Eddystone, mixed with ther crystalline rocks, such as those mentioned by Mr. Arthur Hunt. 3ut if the submarine granite or granites have had no more effect than hat of Dartmoor in uplifting the country, they must be regarded as actors of minor importance in the structure of the Channel anticlinal.

Of course, the probability of an anticlinal axis in the English hannel has long been recognized, and indeed the space between 1e Devon-Cornwall peninsula and Brittany is wide enough for lany a flexure, the mean result being an east-and-west axis of rincipal uplift, the exact position of which it is impossible to DECADE III.-VOI. VI. -NO. XI. 


\section{Reviews -Dr. John Murray-On Marine Deposits.}

determine. Taking a wide geographical view of the subject, we cannot fail to see that there is, first of all on the north, the synclinal of the Glamorganshire coal-field; next the anticlinal of the Bristol Channel, both being rather limited in extent. The second and central synclinal is that of Devonshire, somewhat bulged by the mass of Dartmoor. The succeeding anticlinal of the English Channel was, in all probability, of a very complex nature, bringing up to-day many old and curious rocks, more or less injected by granites, of which we now have the evidence in the Channel Islands, to say nothing of the traces in the bed of the Channel itself, such as Mr. Hunt has so often brought to the notice of the Association.

Beyond this mysterious region of the Channel lies the rocky country of Brittany, which, according to Ur. Barrois, is essentially constituted by a vast geosynclinal depression, running from east to west. The flanks of this great basin consist of very ancient rocks, not quite parallel to each other, but converging somewhat towards the west, and opening out towards the east. The area enclosed has numerous secondary folds, and includes a large series of beds from the Silurian to the Carboniferous. In this region also there are granites, but of more than one age, and Dr. Barrois thinks that they have rather a tendency to follow the anticlinal axes.

Brittany, therefore, constitutes our third great synclinal; but in that country a far lower sequence of beds is brought to-day than in Devonshire, proportionate in fact to the much greater area of the country itself. The principal folding movements there also date from Carboniferous times, and thus the entire region, from South Wales to Brittany inclusive, belongs to what we may call the Hercynian system of mountain-making. It is interesting to note that, in the vicissitudes of time, the three synclinal areas still keep their heads above water, whilst the two areas occupied by the anticlinals are submerged-by no means an uncommon geognostic feature. I am not quite prepared to believe that, on this meridian, the so-called Hercynian system ever attained to any great degree of elevation, though undoubtedly of great width. Its degradation has contributed enormously to the Mesozoic deposits, and in a lesser degree perhaps to the Tertiaries of the country to the eastward.

(To be concluded in the December Number.)

IFVエ耳W $\mathrm{F}$.

\section{I.-Marine Deposits in the Indian Odean.}

"On Marine Deposits in the Indian, Southern, and Antarotio Oceans." By John Murray, LL.D., F.R.S.E. Scottish Geographical Magazine, vol. v. (1889), pp. 405-436, woodcuts 1-12. IN November, 1887, Dr. John Murray communicated to the Scottish Geographical Magazine an account of the marine deposits in the deeper regions of the Indian Ocean, mainly based upon materials obtained by Captain J. P. Maclear, of H.M.S. Flying Fish. Subsequent investigations by Captain Pelham Aldrich in H.M.S. Egeria, and Captain A. Carpenter in H.M.S. Investigator, in addition to 